\title{
MARITIME DIPLOMACY SEBAGAI STRATEGI PEMBANGUNAN KEAMANAN MARITIM INDONESIA
}

\author{
Muhammad Harry Riana Nugraha dan Arfin Sudirman \\ Alumnus Diplomasi Pertahanan Universitas Pertahanan Indonesia dan Dosen Hubungan \\ Internasional, Fakultas Ilmu Sosial dan Ilmu Politik, Universitas Padjadjaran \\ E-mail: arfinsudirman@gmail.com
}

\begin{abstract}
ABSTRAK
Kondisi alamiah geografis Indonesia yang dikategorikan sebagai maritim seharusnya menjadi nilai tambah bagi diplomasi Indonesia terutama untuk kepentingan pembangunan Indonesia. Sehingga secara geokultur, seharusnya Diplomasi Maritim menjadi salah satu pilar utama dalam pembangunan keamanan maritim di Indonesia termasuk penggunaan diplomasi maritim dalam merespon terhadap gangguan keamanan, sehingga secara berangsur kapabilitas pertahanan akan terbangun. Artikel ini akan mengulas pentingnya menata sektor maritim Indonesia pada visi Global Maritime Fulcrum (GMF) dengan melihat kekuatan dan kelemahan kapabilitas TNI AL sebagai salah satu instrumen diplomasi Maritim menuju pembangunan keamanan maritime Indonesia. Artikel ini juga berargumen bahwasanya hal terpenting yang perlu menjadi prioritas Diplomasi Maritim Indonesia adalah mampu menjamin keamanan maritim bagi stakeholders di kawasan regional dan global. Indonesia perlu melakukan penataan dan promosi terhadap pelabuhan perdagangan yang sudah dimiliki, yaitu di Jakarta dan Surabaya serta pelabuhan lainnya sebagai salah satu simpul maritim global yang prospek. Meningkatkan pengamanan dan keamanan sehingga berbagai kerja sama akan terus berlangsung dan bisa mendatangkan keuntungan bagi Indonesia.
\end{abstract}

Kata Kunci: Diplomasi Maritim, Keamanan Maritim, Global Maritime Fulcrum (GMF), TNI AL

\section{MARITIME DIPLOMACY AS A STRATEGY DEVELOPING MARITIME S ECURITY IN INDONESIA}

\begin{abstract}
Indonesia's geographical conditions that sourrounded by ocean should be considered as an added value for maritime diplomacy for the sake of the development of Indonesia. Therefore, in terms of geoculture, Maritime Diplomacy should be taken into account as one of the main pillars to build maritime security in Indonesia including the use of maritime diplomacy in response to security threats, so that the defense capabilities will be gradually improved. This article will examine the importance of organizing Indonesia's maritime sector regarding the vision of the Global Maritime Fulcrum (GMF) in order to see the strengths and weaknesses of Indonesian Navy's capabilities as an instrument of Indonesia's Maritime diplomacy to support the development of maritime security. This article also argued that the most important in Indonesia 's Maritime Diplomacy is that Indonesia is capable to guarantee maritime security for all stakeholders regionally and globally. Indonesia needs to improve management and expand promotion for all trading ports available, namely Jakarta and Surabaya as well as other ports as a hub of global maritime prospects. By enhancing maritime safety and security, various international cooperation will be maintained and profitable for Indonesia.
\end{abstract}

Keywords: Maritime Diplomacy, Maritime Security, Maritime Fulcrum Global (GMF), Indonesian Navy 


\section{PENDAHULUAN}

Sektor maritim Indonesia dalam kalkulas ekonomi berdampak pada arus lintas perdagangan dunia dengan nilai kontribusi USD40 milyar. Akibat kejahatan berupa pencurian ikan ilegal dan sejumlah kerugian lainnya di wilayah perairan Indonesia secara tidak langsung berpotensi mengalami kerugian USD24 milyar per tahunnya. Dengan demikian, diharapkan kemajuan berupa keamanan sektor maritim Indonesia akan mendukung terhadap ekonomi nasional, sehingga mampu menguatkan keamanan dan pertahanan negara.

Berbagai kegiatan perdagangan internasional dipengaruhi dinamika pertumbuhan ekonomi dunia di antaranya terlihat dengan peningkatan armada kapal yang berlayar melalui Selat Malaka, Selat Sunda, dan Selat Lombok melalui ALKI I, II dan III. Data menunjukkan bahwa jumlah kapal yang melalui Selat Malak sejak tahun 1999-2008 meningkat sebanyak 74 persen dan data dari Kementerian Pertahanan memprediksikan akan ada 114.000 kapal yang menggunakan wilayah Selat Malaka pada tahun 2020 (Sheldon, 2010: 3). Kepulauan Indonesia dengan kekayaan maritimnya dan kepentingan maritim yang diusung pada periode pemerintahan Joko Widodo, yaitu Global Maritime Fulcrum (GMF) akan menjad daya tarik bagi dunia internasional karena pertumbuhan ekonomi terbesar salah satunya berasal dari sektor maritim. Selat Malaka, Selat Singapura, Selat Sunda, Selat Makasar, da Selat Lombok bukan saja merupakan tiga jalur utama pelayaran di Asia Tenggara, tetapi juga merupakan jalur pelayaran vital bagi dunia (Noivong, 2011: 14). Berdasarkan hal tersebut, sektor maritim mempunyai efek besar terhadap kesejahteraan dan keamanan, sehingga akan mendukung kestabilan pasar global melalui perdagangan berbagai komoditi pada jalur laut tersebut.

Trend terbaru dari globalisasi adalah adanya kompetisi sumber daya, pertumbuhan penduduk dan perubahan iklim. Maka Indonesia perlu merubah sektor kemaritiman dari sat keterhubungan kepada berbagai keterhubungan dengan membangun infrastruktur baru untuk mendukung pertumbuhan bisnis Indonesia yang diharapkan dapat berdampak pada segi keamanan dan kesejahteraan negara. Bagi negara adidaya, seperti Amerika Serikat, kepentingan terhadap Selat Sunda, antara lain, adalah untuk mobilisasi armada militer dari dan menuju Laut China Selatan Selai itu $66 \%$ dengan total nilai US\$5,2 melewati Laut Tiongkok Selatan. Sebanyak US $\$ 1,2$ trilliun diantaranya terkait langsung dengan kepentingan AS akan kebutuhan energi. Kepentingan Amerika Serikat juga tidak jauh dari orientasi Freedom of the sea and freedom of navigation menjadi prinsip utama armada lau Amerika Serikat (Hume, 2009: 26). Langkah Amerika Serikat tersebut, terlihat adanya penggunaan diplomasi maritim sebagai instrumen penting dalam mencapai kepentingannnya Sebagai sebuah negara, Indonesia juga perlu melihat kapada dunia yang lebih luas untuk membentuk dan memberikan pengaruh pada lingkungan internasional, melalui penggunaa diplomasi maritim. Strategi ini menjelaskan bagaimana mengorganisasikan kapabilitas nasional yang dimiliki, diarahkan dan ditujukan pada isu keamanan maritim secara domestik dan global, serta diproyeksikan pada peningkatan kemampuan untuk menguasai sektor maritim global. Dengan demikian secara jangka panjang akan efisien dalam menggunakan dan menyediakan berbagai sumber daya guna kepentingan nasional.

\section{HASIL DAN PEMBAHASAN}

\section{Diplomasi Maritim}

Diplomasi maritim adalah istilah yang berlaku untuk berbagai macam kegiatan di wilayah maritim atau perairan dalam hal in gugus tugas utamanya ada pada Angkatan Laut suatu negara berdaulat. Pada masa damai diplomasi maritim ini dilakukan untuk mempengaruhi perilaku dari negara lain dalam konteks interaksi dan transaksi yang terjadi $\mathrm{d}$ wilayah perairan. Hal lain juga disebutkan bahwa diplomasi maritim disamakan dengan diplomas angkatan laut. Tetapi, disisi lain, penggunaan atau ancaman Angkatan Laut terbatas oleh pemerintah, dari suatu tindakan perang, untuk menjamin keuntungan atau mencegah kerugian. Diplomasi maritim merupakan bentuk penggunaan kekuatan angkatan laut yang terbatas dalam spektrum yang bergerak dar pelabuhan kunjungan oleh kapal perang kepada kebebasan navigasi latihan di laut dan kegiatan di sekitar pesisir pantai. Tindakan ini dapat dikategorikan sebagai diplomasi koersif yang menggunakan Angkatan Laut untuk mengirim sinyal niat, dukungan dan perhatian, atau untuk memaksa perubahan dalam perilaku negara lain.

Tidak ada definisi khusus dari diplomasi maritim, yang jelas adalah diplomasi maritim tidak sama dengan Gun Boat Diplomacy atau diplomasi kapal perang dan Naval Diplomacy. Hal ini berbanding terbalik dengan pernyataan berikut: 'Gun Boat diplomacy is the overt display, demonstration, threat or use of limited sea based force by state or non-state actor designed to coerce an opponent to further a political goal, often unstead, by compellence or detterence'. (Sir James Cable dalam Griffin, $2005: 109$ ).

Berdasarkan pengertian di atas, seringkali ancaman atau penggunaan kekerasan berbasis laut terbatas oleh negara atau aktor non negara yang dirancang untuk memaksa lawan untuk memajukan tujuan politik. Diplomasi maritim, mengharuskan angkatan laut, coast guard dan semua kekuatan laut adalah alat negara yang dapat digunakan untuk kepentingan operasi maritim dan diplomasi maritim.

Diplomasi maritim ditujukan untuk keperluan penggetar negara lain atau deterrence, yang bisa dipahami sebagai penggunaan ancaman oleh salah satu pihak penangkalan dalam konteks strategi militer untuk meyakinkan pihak lain dalam menahan dan menangkal berbagai berfungsi sebagai pencegah yang meyakinkan target agar tidak melaksanakan tindakan yang kan mereka lakukan karena biaya dan kerugian yang akan ditimbulkannya. Dalam konteks keamanan internasional, efek deterrence umumnya mengacu pada ancaman pembalasan militer yang diarahkan untuk mencegah negara lain untuk melakukan kegiatan yang dapat merugikan negara yang melakukan kebijakan deterrence tersebut dan umumnya terbatas pada penggunaan senjata nuklir (perspektif Perang Dingin). Oleh Karena itu, perlu adanya pelaksanaan konsep poros maritim yang mendahulukan implementasi kedaulatan di laut dan penyelesaian batas-batas laut serta penguatan pertahanan di laut dan memastikan efek deterrence berjalan sebagaimana semestinya.

Pada konteks indonesia yang memiliki dan mengusung kebijakan poros maritim sangat ideal untuk dikembangkan sekaligus peletakkan dasar diplomasi maritim yang ditujukkan pada dunia internasional. Oleh karenanya selaras dengan uraian di atas, Indonesia memerlukan infrastruktur dan penyiapan berbagai perangkat yang terlibat dalam pelaksanaan diplomasi maritim pada konteks poros maritim dunia dengan melihat juga pengertian Keamanan Maritim secara umum.

\section{Konsep Keamanan Maritim}

Munculnya isu keamanan maritim diawali dengan fungsi wilayah perairan yang semakin strategis bagi kepentingan negara-negara dunia. Menurut Susanto dan Munaf (2014: 48 50 ), wilayah maritim merupakan urat nadi utama interaksi ekonomi global, sehingga menjadikan keamanan maritim isu krusial bagi banyak negara di dunia. Stabilitas keamanan maritim sangat diperlukan seluruh negara di dunia dalam rangka menjaga kepentingan nasional bangsa yang berdampak pada pembangunan nasional.

Keamanan maritim merupakan sebagian kecil dari keamanan nasional, sehingga praktek keamanan nasional suatu negara menentukan bagaimana praktek keamanan maritim dalam kebijakan nasional (Octavian \& Yulianto, 2014: 159-160). Menurt 159-160). Menunt Makn (2009: 118), sedang diperbincangkan banyak pihak, belum ada satupun pihak yang mencetuskan definis utuh dari keamanan maritim karena masalah ini dinilai terlalu sensitif khususnya dalam hal batas laut suatu negara. Menurut Roell et.al (2013. 2) sekalipun konsep keamanan maritim belum rigid, namun perlu dibedakan antara keamanan maritim dengan keselamatan maritim, yaitu keamanan maritim sifatnya merujuk pada tindakan yang sifatnya preventif dan responsi untuk melindungi wilayah maritim suatu negara dari ancaman terhadap keamanan maupun tindak pelanggaran hukum lainnya, sedangkan keselamatan maritim menekankan pada mencega/mengurangi dampak dari kecelakanbencana alam. Seperti yang dikemukakan Roell sebagai berikut: "Maritime Security... which has no clear definitions when it comes to Maritime Security Operations........no universal legal or agreed definition due to the fact that it is a broad topic, covering many policy sectors" (Roell et al, 2013: 2)

Konsep keamanan maritim berada di antara kerangka keamanan tradisional dan non- 
tradisional. Berdasarkan kerangka keamanan tradisional, pelanggaran terhadap keamanan maritim dianggap mengancam kedaulatan dan identitas negara, sedangkan kerangka nontradisional cenderung memperluas bentang keamanan dari objek acuan sehingga masalahmasalah kemaje

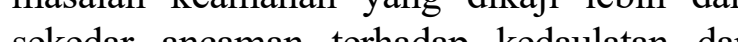
idedar ancanan terhadap kedaulan dan identitas negara, seperti Suku Agama Ras dan Antargolongan (SARA), ekonomi, migrasi, lingkungan hidup, serta sumber daya. Bahkan menurut Timothy D. Hoyt dalam Keliat (2009: 113), fokus kepedulian keamanan non-tradisional harus dialihkan dari negara menjadi kelompok atau individu dengan isu-isu yang bersifat non-militer seperti keamanan ekonomi, lingkungan, politik, termasuk keamanan maritim.

Perkembangan Konsep Keamanan Maritim

Konsep keamanan maritim berawal dar resolusi majelis umum PBB yaitu Informal Consultative Process (ICP) yang mengeluarkan dokumen-dokumenmengenai ancaman terhadap perdamaian dan keamanan internasional yang datang dari laut berupa praktek kegiatan ilegal seperti perdagangan gelap narkotika, migrasi ilegal, serta kejahatan terorganisir (ICP PBB, 2001: 2). Menurut Geoffrey Till dalam Kelia (2009: 115), keamanan merilim meupakan sebuah istilah baru yang ruang lingkupnya tidak lagi membahas hal-hal yang bersifat tradisional seperti pengendalian dan ekspedisi militer laut, melainkan menjaga ketertiban di laut yang menjadi sumber daya alam, sarana transportasi, dan aspek penting dalam lingkungan hidup.

Namun semenjak peristiwa 9/11, komunitas maritim internasional meninjau kembali hukum tentang keamanan di laut: International Convention of Safety of Life at Sea (SOLAS) untuk melindungi pelabuhan dan kapal di seluruh dunia dari ancaman terorisme. Berdasarkan konvensi tersebut terciptalah International Ship and Port Facility Security Code (ISPS Code) serta amandemen SOLAS 74 yang menjadi standar keamanan di industri maritim untuk mencegah tindak kejahatan di laut seperti pembajakan, penyanderaan, penyelundupan penyalahgunaan fungsi kapal serta perusakkan kargo (IMO, 2015)

IMO. 2015. "International Convention for the Safety of Life at Sen SOLAS), 1974, diakseses dari hitp://www.imo.orgen/About Convention Life-at-Sea-\%28SOLAS\%29\%2c-1974.aspx pada 28 Oktober 2015
Pada pertemuan ICP tahun 2002, masih belum ditemukan definisi yang rigid mengena konsep keamanan maritim, namun untuk pertama kalinya dicetuskan istilah keamanan dan keselamatan maritim yang harus menjadi salah satu prioritas dan segala kejahatan yang terjadi di laut merupakan ancaman yang serius. Dalam dokumen ini juga menyertakan peran serta aktor non-negara seperti organisasi maritim internasional (IMO).

Pada pertemuan ICP tahun 2005, disebutkan bahwa "negara-negara harus bertindak secara ketat sesuai dengan hukum laut internasional dan menghindarkan penerapan kebijakan-kebijakan unilateral apapun yang bertentangan dengan norma-norma hukum yang ada yang berasal dari UNCLOS". Kemudian pada tahun 2006, keamanan maritim menjadi salah satu dari empat isu utama pertemuan ICP, pada saat ini pembahasan tentang isuisu keamanan maritim lebih terfokus, namun demikian, definisi keamanan maritim belum dapat ditetapkan, yang ada hanya kesepakatan mengenai komponen ancaman yang dianggap membahayakan keamanan maritim, yaitu (The Present Addendum to the Report of the SecretaryGeneral on Oceans and the Law of the Sea (A/63/63):

1. Tindakan teroris terhadap pelayaran kapal dan instalasi lepas pantai (terrorist acts against shipping and offshore installations)

2. Pembajakan dan perampokan bersenjata (piracy and armed robbery against ships) 3. lalu lintas obat terlarang dan narkrotik yang ilegal dan zat-zat psikotropik (illicit traffic in narcotic drugs and psychotropic substances).

Menurut McNicholas (2008: 1-2), keamanan maritim adalah langkah-langkah yang diambil oleh pemilik, operator, administrator kapa fasilitas pelabuhan, instalasi lepas pantai, serta organisasi kelautan untuk melindungi wilayah laut dari pembajakan, sabotase, penyitaan, pencurian, dan gangguan lainnya. Kesulitan dalam merumuskan konsep keamanan maritim dapat dikatakan terjadi karena menghindari tindakan pre-emptive terhadap forum-forum keamanan maritim yang berada di luar mekanisme PBB, keinginan pemisahan konsep keamanan maritim dengan keselamatan maritim, serta definis keamanan maritim yang kaku mengakibatkan berkurangnya otoritas keamanan nasional dalam pengelolaan laut. Hal ini berarti keamanan maritim tidak hanya berfokus pada aksi militer (gencatan senjata) saja, tetapi juga aktivitas perikanan, pencemaran laut yang disengaja, serta kegiatan penelitian atau survei yang bertempat di laut.

Ruang Lingkup Keamanan Maritim

Ditemukannya tantangan dan ancaman terhadap keamanan maritim tersebut di atas mendorong banyak pihak untuk mengkonstruksikan konsep keamanan maritim dalam rangka menyelesaikan persoalan keamanan maritim itu sendiri. Masalah keamanan maritim merupakan masalah keamanan yang kerap terjadi di wilayah perairan laut, dengan kata lain menggunakan laut sebagai media/tempat kejahatan/tindak pelanggaran hukum dilakukan, seperti kejahatan terorganisasi lintas negara: pembajakan/perompakan laut, imigran gelap, perdagangan narkoba, penyelundupan serta pencurian ikan yang sering diidentikkan sebagai persoalan utama dalam keamanan maritim.

Mayoritas ancaman yang terjadi dalam ruang lingkup keamanan maritim merupakan ancaman non-tradisional seperti terorisme maritim,separatisme,radikalismeyangberujung pada konflik komunal dengan laut sebagai medianya, kerusuhan sosial antarpengguna laut, perompakan dan pembajakan di laut, imigran ilegal, penangkapan dan pembalakan ilegal, serta penyelundupan dan pencemaran laut (Buku Proceeding Seminar Markas Besar AL, 2007).

Kejadian-kejadian yang mengancam keamanan maritim memunculkan aturan-aturan berupa tindakan pencegahan serta inisiatif yang bertujuan menjaga keamanan kekayaan maritim. Contoh aturan-aturan tersebut tertulis dalam ISPS (International Ship and Port Security), PSI (Proliferation Security Initiative), CODE by IMO (International Maritime Organization) (Buku Proceeding Seminar Markas Besar AL, 2007).

Menurut salah satu peneliti senior pada Centre for Strategic and International Studies (CSIS), Anggoro (2007), keamanan maritim tidak mungkin hanya menjadi tanggung jawab suatu instansi tunggal karena karakternya yang memiliki kedaulatan ganda, ketidakjelasan tapal batas dan permeabilitasnya yang tinggi.
Oleh karena itu, jika strategi pembangunan keamanan maritim Indonesia bertumpu kepada kepiawaian diplomasi maritime TNI AL, maka penting untuk memahami dan mengembangkan doktrin maritim Indonesia yang memang rawan tumpang tindih kedaulatan dengan negara lain.

\section{Doktrin Maritim Indonesia}

Indonesia akan mencapai tujuan tersebut dengan memfokuskan pada visi Global Maritime Fulcrum (GMF). Dengan memperhatikan berbagai resiko yang diha-dapi, berbagai pendekatan perlu dilakukan gun menyeimbangkan pencapaian visi dan hambatanhambatan yang mungkin terjadi. Termasuk penggunaan diplomasi maritim dalam merespon terhadap gangguan keamanan, sehingga secara berangsur kapabilitas pertahanan akan terbangun. Hal ini membutuhkan pendekatanpendekatan strategis dari pemerintah terhdap ancaman maritim dengan mengumpulkan informasi selengkap mungkin sebelum pengambilan keputusan. Berdasarkan hal tersebut, dukungan dari ikatan kerja sama regional dan multilateral akan sangat membantu dalam melangsungkan pencapaian visi maritim Indonesia Masa depan maritim Indonesia akan terlihat pada kemampuannya mempengaruhi kebutuhan global untuk mencapai kondisi aman dan memiliki mobilitas perdagangan dan aktifitas bisnis yang stabil dan berkelanjutan. Hal erpenting adalah mampu menjamin keamanan maritim bagi stakeholders di kawasan regiona dan global. Indonesia perlu melakukan penataan dan promosi terhadap pelabuhan perdagangan yang sudah dimiliki, yaitu di Jakarta dan Surabaya serta pelabuhan lainnya sebagai pusat dari aktifitas maritim global yang prospek Meningkatkan pengamanan dan keamanan sehingga berbagai kerja sama akan terus berlangsung dan bisa mendatangkan keuntungan bagi Indonesia.

Indonesia yang mengusung "Global Maritime Fulcrum" untuk menjadi garda terdepan kepentingan nasional Indonesia secara domestik dan internasional. Berdasarkan hal tersebut berbagai resiko dan peluang dar sektor maritim yang dikembangkan dengan tujuan penguatan dan pencapaian keamanan untuk membantu membentuk stabilitas dunia Strategi ini ditempatkan pada domain maritim pada konteks permasalahan tersebut. Hal in 
dibentuk dan dilakukan dengan pendekatan berdasarkan tujuan yang akan dicapai di mas yang akan datang. Pada akhirnya struktur pemerintahan yang akan menentukan efektifitas dan efisiensi penataan sektor maritim Indonesia Permasalahan yang dihadapi secara mayoritas adalah ancaman terhadap sumber daya, berup kriminalitas, terosisme hingga kejahatan kemanusiaan (Gandarsih dan Priamarizki, 2015: 5) Sehingga membutuhkan regulasi yang kuat dan kebijakan internasional yang jelas serta kerja sama komprehensif secara global yang ditujukan pada keamanan bersama. Domain maritim sangat komplek dalam sistem internasiona dimana Indonesia perlu memainkan peran diplomasi dan penguatan kemampuan militer serta industri pertahanan.

Tantangan Diplomasi Maritim Indonesia Kelemahan Indonesia adalah belummampu berkompetisi pada aspek kebijakan, militer, dan kapabilitas diplomasi pada tataran global. Padahal sebenarnya, Indonesia adalah pusat dari maritime domain dunia yang mencakup ketiga aspek tersebut. Seharusnya sudah mampu mulai melakukan pengauatan infrastruktur sehingga tiga sektor lainnya akan iikut tergerakkan, yaitu ekonomi, kelautan dan perikanan, serta energi. Global Maritime Fulcrum sangat strategis di masa depan dalam isu-isu maritim dunia, oleh karenanya Indonesia perlu memaksimalkan upaya dan fokus terhadap kerjasama yang terintegrasi jika memungkinkan untuk dijalankan Aspek sumber daya manusia dan teknolog perlu ditingkatkan melalui pendidikan dan rise serta joint research dengan negara lain dalam ikatan kerja sama pertahanan keamanan maupun sektor maritim secara berkelanjutan.

\section{Stabilitas Keamanan Maritim Indonesia}

TNI Angkatan Laut (TNI AL) Indonesia juga menempati posisi dan porsi yang strategis untuk mengupayakan optimalnya implementas visi maritim dunia. Melakukan operasi dengan dukungan peralatanAlutsistayang canggih akan mempercepat pengawalan bagi pemerinta mencapai visi tersebut, memberikan gambaran bagi negara lain dan membangun pelaksanaan diplomasi (naval diplomacy) secara efektif. Pemerintah dan angkatan laut dapat melakukan beberapa upaya, diantaranya: modernization, build up, dan naval deployment. Dinamika yang berkembang juga perlu menjadi respon bagi Indonesia dalam menata pencapaian vis maritim dunia Gejolak Laut Cina Selatan yang sampai sejauh ini belum menemukan suatu titik terang, menjadi lahan diplomasi maritim Indonesia secara berkelanjutan. Penyaiapan sumber daya strategis dan penguatan angkatan bersenjata merupakan bentuk kolaborasi efektif yang harus dikedepankan dalam kurun waktu sepuluh tahun kedepan.

Organisasi regional Association of South East Asian Nation (ASEAN) dapat menjad wadah sekaligus wabah bagi kelangsungan pencapaian visi maritim dunia Indonesia. Menjadi wadah bagi kegiatan diplomasi maritim dan melangsungkan serangkaian agenda strategis bidang kemaritiman Indonesia. Menjadi wabah, negara-negara asean akan menjadi batu sandungan apabila tidak tegas dan jelas dalam menentukan sikap yang kaitannya dengan kedaulatan dan kepentingan nasional Indonesia. Oleh karena itu, penggunaan diplomasi maritim secara efektif akan berdampak positif terhadap organisasi regional tersebut untuk kepentingan maritim Indonesia.

Analisis terhadap kemanan maritim Indonesia adalah penangkalan sekaligus penyelesaia berbagai kriminalitas di wilayah perairan Indonesia. Terorisme, perdagangan ilegal, serangan laut, dan penyelundupan manusia. Oleh karen itu Indonesia perlu melakukan berbagai langkah strategis, diantaranya yang bisa dilakukan:

1. Memosisikan keamanan maritim internasional melalui karakteristik dan nilai strategis maritim Indonesia.

2. Mengembangkan pemerintahan atau tata kelola maritim dan kapabilitas negara secara strategis.

3. Melindungi segenap bangsa Indonesia, terutama yang berada di wilayah perbatasan dengan memberikan kepastian ekonom secara bertahap.

4. Menata infrastruktur laut dan keterhubungan rute perdagangan, antara angkatan laut Indonesia, kawasan regional, dan internasional.

5. Melindungi wilayah dan populasi penduduk dari bahaya organisasi ilegal dan kejahatan serta terorisme melalui wilayah perairan wilayah rentan dengan kejahatan tersebut.
Sejumlah kerja sama industri pertahanan yang sudah dijalin Indonesia perlu diadopsikan kedalam kebijakan industri pertahanan melalui komite kerja sama industri pertahanan dengan berbagai negara. Dalam jangka panjang produksi produk Alutsista maritim akan membentuk wajah industri pertahanan dan akan menaikkan taraf ekonomi nasional.

\section{SIMPULAN}

Berkaitan dengan aktifitas kerja sama internasional pada kerja sama industri kapal selam dan Alutsista maritim lainnya merupakan poin penting bagi Indonesia sebagai suatu strategi. Berbagai aktifitas yang dipromosikan oleh United Nation (UN) seperti the International Oceanographic Committee of the United Nations Educational, sebagai saluran efektif untuk melangsungkan diplomasi dan kepentingan maritim. Indonesia perlu mengambil peranan pada aktifitas kemaritiman dunia, diantaranya bisa aktif berkonsentrasi terhadap the Global Studies and Monitoring of Marine Pollution (GSMMP); the Tropical Ocean and Global Atmospheric Project (TOGA): the World Ocean Experiment (WOCE); the Joint Global Ocean Flux Study (JGOFS); the Land-ocean Interaction in the Coastal Zone (LOICE); and the Global Ocean Ecosystem Dynamics (GLOBEC). Masa depan industri kemaritiman Indonesia sudah jelas, disamping sebagai sebuah strategi dalam pengembangan produk Alutsista bagi pertahanan nasional juga sebagai dimensi pendukung diplomasi maritim Indonesia di masa depan. Ada beberapa strategi yang bisa dilakukan Indonesia: Pertama, kebijakan pengembangan sumber daya kelautan yang komprehensif dipromosikan melalui kebijakan industri maritim secara terintegrasi. Hal tersebut akan angat memungkinka industry dan kesiapan kekuatan pertahanan dalam menjaga keamanan dan stabilitas maritim global. Kedua, kerja sama internasional melalui penggunaan diplomasi maritim mendapatkan dukungan dari pemerintah berupa aktifasi badan dan lembaga kemaritiman seperti Bakamla TNI $\mathrm{AL}$, dan lembaga lainnya. Dukungan penuh dan sinergi antara lembaga tersebut juga perlu terintegrasi langsung dengan Komite Kebijakan Industri Pertahanan (KKIP) yang khusus merevitalisasi dan mengembangkan industri pertahanan.
Ketiga, kebijakan pengembangan diarahkan pada penelitian, pendidikan, pengelolaan industri kemaritiman yang mengedepankan teknologi dan pembangunannya yang berkelanjutan. Karena bagaimanapun dukungan dari aspek ini memiliki peran strategis. Disamping itu, penguatan kelembagaan sektor maritim Indonesia, dari tingkat kementerian, badan atau lembaga terkait serta pemangku kepentingan lainnya perlu secara serius dilakukan mulai dari sekarang.

\section{DAFTAR PUSTAKA}

Berridge, G.R, dan James, Alan. 2003. A Dictionary of Diplomacy. New York: Palgrave Macmillan

Booth, Gore. 1979. Satow's Guideto Diplomatic Practice Fifth ed. New York: Longman

Buzan, Barry. 1998. Security: ANew Framework for Analysis. USA: Lynne Rienner Publishers In

Butler. Colin J. (2005) Strategic Alliance UK, Journal, Jan - Feb Edition. Strategic Change 14: 20-22

Dewan Kelautan Indonesia. 2011. Maritime Security Policy. Jakarta: Kementerian Kelautan dan Perikanan.

Gandarsih, Iis dan Priamarizki, Adhi. 2015. Indonesia's Maritime Doctrine and Security Concern. Indonesia Program. Policy Working Paper. RSIS.

Huth, P. K. 1999. Deterrence and International Conflict: Empirical Findings and Theoretical Debate. Annual Review of Political Science.

International Organization for Migration. 2009. The International Organization for Migration and Penyelundupan manusia. Switzerland: IOM.

International Organization for Migration. 2015. FGD tentang Keamanan Maritim: Laut Kunci Masa Depan Indonesia. Jakarta: IOM.

Keliat, Makmur. 2009. "Keamanan Maritim dan Implikasi Kebijakannya Bagi Indonesia". Jakarta: Jurnal Ilmu Sosial dan Ilmu Politik. 
Le Mière. 2014. Maritime Diplomacy in the 21 st Century: Drivers and Challenges. Routledge, New York.

Marsetio. 2014. Sea Power Indonesia. Jakarta: UNHAN.

McNicholas, Michael. 2008. "Maritime Security an Introduction”. Oxford: Elsevier

IMO. 2015. "International Convention for the Safety of Life at Sea (SOLAS), 1974", diakses dari http://www.imo.org/en/ About/Conventions/ListOfConventions/ Pages/International-Conventionfor-the-Safety-of-Life-at-Sea$\% 28$ SOLAS\%29\%2c-1974.aspx pada 28 Oktober 2015

Noivong, Thassarany. 2011. "Moving Beyond "Hub-and-Spokes"System:US-ASEAN Non-Traditional Security and Multilateral Cooperation “. Dipresentasikan dalam Third Global International Studies Conference, Portugal.

Octavian, Amaruli dan Yulianto, Bayu. 2014. Budaya, Identitas \& Masalah Keamanan Maritim. Jakarta: Universitas Pertahanan Indonesia.
Pernyataan Duta Besar Amerika Serikat untuk Indonesia, H.E.Cameron Hume, dalam Penyerahan Hasil PreFeasibility Study Jembatan Selat Sunda kepada Pemerintah RI. Tanggal 9 Agustus 2009.

Sheldon, Simon. 2010. "Safety and Security in the Malaca Strait: The limits of Collaboration", The National Bureau of Asian Research.

Simon. W. Sheldon, "Safety and Security in the Malaca Strait: The limits of Collaboration", The National Bureau of Asian Research, November 2010.

Susanto \& Dicky Munaf. 2015. Komando dan Pengendalian Keamanan dan Keselamatan Laut: Berbasis Sistem Peringatan Dini. Jakarta: Gramedia Pustaka Utama.

Thassarany Noivong, Moving Beyond "Huband-Spokes" System: US - ASEAN Non Traditional Security and Multilateral Cooperation.

Till, Geoffrey. 2004. "Good Order at Sea; Revisiting the Imperative". United Kingdom: KCL Corbett Centre. 